University of Nebraska - Lincoln

DigitalCommons@University of Nebraska - Lincoln

Agronomy \& Horticulture -- Faculty Publications

Agronomy and Horticulture Department

$5-31-2008$

\title{
Crop Nitrogen and Phosphorus Utilization following Application of Slurry from Swine Fed Traditional or Low Phytate Corn Diets
}

\author{
J. S. Paschold \\ USDA-ARS
}

B. J. Wienhold

USDA-ARS, Brian.Wienhold@ars.usda.gov

Dennis L. McCallister

University of Nebraska-Lincoln, dmccallister2@unl.edu

Richard B. Ferguson

University of Nebraska-Lincoln, rferguson1@unl.edu

Follow this and additional works at: https://digitalcommons.unl.edu/agronomyfacpub

Part of the Plant Sciences Commons

Paschold, J. S.; Wienhold, B. J.; McCallister, Dennis L.; and Ferguson, Richard B., "Crop Nitrogen and Phosphorus Utilization following Application of Slurry from Swine Fed Traditional or Low Phytate Corn Diets" (2008). Agronomy \& Horticulture -- Faculty Publications. 119.

https://digitalcommons.unl.edu/agronomyfacpub/119

This Article is brought to you for free and open access by the Agronomy and Horticulture Department at DigitalCommons@University of Nebraska - Lincoln. It has been accepted for inclusion in Agronomy \& Horticulture -Faculty Publications by an authorized administrator of DigitalCommons@University of Nebraska - Lincoln. 


\title{
Crop Nitrogen and Phosphorus Utilization following Application of Slurry from Swine Fed Traditional or Low Phytate Corn Diets
}

\author{
J. S. Paschold, B. J. Wienhold,* D. L. McCallister, and R. B. Ferguson
}

\begin{abstract}
Field application of swine (Sus scrofa) slurry provides essential nutrients for crop production. The $\mathrm{N}$ to $\mathrm{P}$ ratio for slurry is lower than needed by most crops resulting in $\mathrm{P}$ accumulation when applied at $\mathrm{N}$ rates required for crop growth. Low phytate corn (Zea mays L.) (LPC) contains similar amounts of total $\mathrm{P}$ but less phytate $\mathrm{P}$ than traditional corn (TC) resulting in improved $\mathrm{P}$ bioavailability and reduced $\mathrm{P}$ excretion by monogastric animals. While manure from swine-fed LPC diets has a higher N to $\mathrm{P}$ ratio than that from TC diets, field studies comparing crop utilization of nutrients from LPC manure have not been conducted. A field study was conducted to compare $\mathrm{N}$ and $\mathrm{P}$ utilization by no-tillage rainfed sorghum [Sorghum bicolor (L.) Moench.] receiving three annual surface applications of nutrients (inorganic fertilizer, LPC slurry, and TC slurry) and by irrigated corn receiving one incorporated application of nutrients. Sorghum grain and total dry matter $\mathrm{N}$ utilization exhibited a year by treatment interaction but total dry matter $\mathrm{N}$ utilization was similar for both manure types in all years $(61.2 \pm 2.6 \%$ for $\mathrm{TC}$ and $53.8 \pm 2.6 \%$ for LPC). Grain P utilization was similar for inorganic fertilizer and manure but differed among years $(44.4 \pm 7.0 \%$ in $1999,25.1$ $\pm \mathbf{1 . 4 \%}$ in 2000 , and $57.0 \pm 2.2 \%$ in 2001). Corn grain $\mathrm{N}$ and $\mathrm{P}$ utilization did not differ among nutrient sources in the year of application $(50.7 \pm 2.4 \%$ for $\mathrm{N}$ and $40.4 \pm 3.0$ for $\mathrm{P})$ and increased little in the year following application $(62.2 \pm 3.0 \%$ for $\mathrm{N}$ and $50.2 \pm 4.5 \%$ for P). Crop N and P utilization from LPC manure and TC manure was similar and nutrient guidelines developed for TC swine slurry should also apply for LPC slurry.
\end{abstract}

Wine PRODUCTION is a major component of the $\checkmark$ American farm economy and generates large amounts of manure. While this manure contains nutrients essential for crop production these nutrients are often present in a different proportion than is required by a growing crop. For example slurry usually has a lower $\mathrm{N}$ to $\mathrm{P}$ ratio (e.g., 3:1) than is required by the crop (e.g., corn grain has a $\mathrm{N}$ to $\mathrm{P}$ ratio of 6:1). Land application of slurry at rates to meet the $\mathrm{N}$ needs of a crop requires the least amount of land and is more economical than application at rates to meet the P needs of a crop (Lory et al., $2004 a, b)$. However, application of slurry at rates to meet the $\mathrm{N}$ needs of the crop can result in accumulation of $\mathrm{P}$ which increases the potential for negative environmental impacts (Sharpley et al., 1994).

The low $\mathrm{N}$ to $\mathrm{P}$ ratio in swine slurry results from the inability of monogastric animals to efficiently use phytate $\mathrm{P}$ which is the dominant form of $\mathrm{P}$ in most feed grains (Wodzinski and Ulla, 1996). Inefficient utilization of phytate P requires growers to add supplemental $P$ to feed so that animal needs are met. Inefficient utilization of $\mathrm{P}$ results in high $\mathrm{P}$ concentrations in the manure. One approach for reducing the amount of $\mathrm{P}$

J.S. Paschold and B.J. Wienhold, USDA-ARS; D.L. McCallister and R.B. Ferguson, Dep. of Agronomy and Horticulture, Univ. of Nebraska, Lincoln, NE 68583. USDA-ARS, Northern Plains Area, is an equal opportunity/ affirmative action employer and all agency services are available without discrimination. Received 18 July 2007. ${ }^{*}$ Corresponding author (Brian.Wienhold@ars.usda.gov).

Published in Agron. J. 100:997-1004 (2008). doi:10.2134/agronj2007.0248

Copyright (C) 2008 by the American Society of Agronomy, 677 South Segoe Road, Madison, WI 53711. All rights reserved. No part of this periodical may be reproduced or transmitted in any form or by any means, electronic or mechanical, including photocopying, recording, or any information storage and retrieval system, without permission in writing from the publisher. excreted by swine and other monogastric animals is development of feed grains that store $\mathrm{P}$ in a more bioavailable form. Low phytate corn contains a gene that results in grain containing a similar amount of $\mathrm{P}$ as TC but a larger proportion of that $\mathrm{P}$ as phosphate rather than phytate (Ertl et al., 1998). Swine use more P from LPC diets than from TC diets resulting in a reduced need to add supplemental $\mathrm{P}$ and a lower amount of $\mathrm{P}$ being excreted (Spencer et al., 2000).

Previous research has shown that slurry from swine fed an LPC diet has a higher $\mathrm{N}$ to $\mathrm{P}$ ratio (4.5 vs. 3.3) than slurry from swine fed a TC diet (Wienhold and Miller, 2004). Laboratory and greenhouse studies have been conducted to determine if there are differences in the form and availability of $\mathrm{P}$ in manure from LPC diets. Wienhold and Miller (2004) used a sequential chemical fractionation procedure to compare solubility and lability of P in LPC manure to that in TC manure and concluded that while the concentration of total $\mathrm{P}$ was lower in LPC manure than in TC manure the chemical composition of that P was similar. Gollany et al. (2003) conducted a greenhouse study to compare available $\mathrm{P}$ as a function of time for soils receiving inorganic fertilizer P, LPC manure, or TC manure. They concluded that manure available $\mathrm{P}$ was $60 \%$ that of inorganic fertilizer P, total P in LPC manure was lower than in TC manure, and that availability of $\mathrm{P}$ was similar for the two manure types. Gollany et al. (2003) recommended that field studies be conducted to compare the availability of P in TC and LPC manures. We know of no field studies comparing crop nutrient utilization from inorganic P, TC manure, and LPC manure.

The objective of this study was to compare crop $\mathrm{N}$ and $\mathrm{P}$ utilization under field conditions when nutrients were applied as inorganic fertilizer, manure from swine fed a LPC diet, or manure from swine fed a TC diet. Nutrient utilization was

Abbreviations: LPC, low phytate corn; TC, traditional corn. 
compared under two scenarios: (i) utilization of surface applied nutrients by no-tillage sorghum with nutrients applied each spring and (ii) utilization of incorporated nutrients by irrigated corn over two growing seasons.

\section{MATERIALS AND METHODS}

Crop utilization of $\mathrm{N}$ and $\mathrm{P}$ provided as either swine slurry or inorganic fertilizer was determined at two locations, the Rogers Memorial Research Farm near Lincoln, NE and the University of Nebraska South Central Agricultural Laboratory near Clay Center, NE. The study at the Rogers Farm compared $\mathrm{N}$ and $\mathrm{P}$ utilization among nutrient treatments applied for three consecutive years. The study at Clay Center compared $\mathrm{N}$ and $\mathrm{P}$ utilization among nutrient treatments in the year of application and in the year following application. Nutrient treatments for both studies included a control (no nutrients added), inorganic fertilizer ( $\mathrm{N}$ as $\mathrm{NH}_{4} \mathrm{NO}_{3}$ and $\mathrm{P}$ as superphosphate), manure from swine fed a LPC diet, and manure from swine fed a TC diet. Nutrients were applied at rates for an expected sorghum yield of $5.4 \mathrm{Mg} \mathrm{ha}^{-1}$ at the Rogers Farm and an expected corn yield of $8.8 \mathrm{Mg} \mathrm{ha}^{-1}$ at Clay Center. Both manures were added at rates to meet the $\mathrm{N}$ needs of the crop assuming $70 \%$ of the $\mathrm{N}$ in the manure was available to the crop during the growing season (Koelsch and Shapiro, 1997). The two manures differed in nutrient concentration (Wienhold and Miller, 2004) and this difference resulted in year-to-year differences in $\mathrm{N}$ and $\mathrm{P}$ application rates (Table 1).

To generate the two different manure sources, corn exhibiting the low phytate trait (Pioneer variety X1127PP) ${ }^{1}$ and the same variety without the low phytate trait (Pioneer variety Alicia) were grown under irrigation near Shelton, NE in 1998. Recommended practices for irrigation, fertilizer application, and pest control were used to optimize yield. Crops were harvested and stored separately until used as feed. The two corn sources were used to prepare feed appropriate for a starter phase swine diet in the spring of 1999, 2000, and 2001. Each year the two diets were fed to swine in elevated pens with 10 pigs per pen. Each diet was fed to all pigs in six randomly assigned pens. Trays were placed under each pen and slurry (manure and urine) was collected. Slurry from swine fed each of the two diets was stored separately ( $<30 \mathrm{~d}$ ) until needed for field application. During slurry collection and during field application of the slurry (14-30 d after collection) duplicate samples were collected and sent to a commercial laboratory for nutrient analysis. Results from the nutrient analysis of slurry sampled during collection were used to calculate application rates. Results from the nutrient analysis of slurry sampled during field application were used to account for changes in slurry nutrient concentration during storage and to calculate actual nutrient amounts applied (Table 1).

\section{Rogers Farm}

Soil at the Rogers Farm was an Aksarben (formerly Sharpsburg) silty clay loam (fine smectitic, mesic Typic Argiudoll) with a total $\mathrm{N}$ concentration of $1.0 \mathrm{~g} \mathrm{~kg}^{-1}$, an organic C concentration of $10.2 \mathrm{~g} \mathrm{~kg}^{-1}$, a Bray P concentra-

\footnotetext{
${ }^{1}$ Trade or manufacturer's names mentioned do not constitute endorsement,
} recommendation, or exclusion by USDA-ARS or the University of Nebraska. tion of $7.8 \mathrm{mg} \mathrm{kg}^{-1}$, a bulk density of $1.36 \mathrm{~g} \mathrm{~cm}^{-3}$, and a $\mathrm{pH}$ of 5.7 in the 0 - to $15-\mathrm{cm}$ depth. The field had been cropped to a rainfed no-tillage grain sorghum, soybean [Glycine max (L.) Merr.], winter wheat (Triticum aestivum L.) rotation for more than $5 \mathrm{yr}$ and was planted to sorghum the year before this study. Plots received the same manure or fertilizer treatment and crop nutrient utilization (described below) was determined each year. Treatments were surface applied at crop emergence in 1999,2000 , and 2001 to 3.6 by $9.7 \mathrm{~m}$ plots arranged in a completely randomized design with three replications (Table 1). Sorghum (NC+7R37E) was direct-seeded in mid-May each year with a row spacing of $90 \mathrm{~cm}$ at a population of 167,000 plants ha-1.

Precipitation from 1 May through 31 October totaled 47.4 $\mathrm{cm}$ in $1999,39.3 \mathrm{~cm}$ in 2000 , and $37.0 \mathrm{~cm}$ in 2001 compared to the 20 -yr average of $44.6 \mathrm{~cm}$. Accumulated growing degree days (base $10^{\circ} \mathrm{C}$ ) from 1 May to 31 October were $1842^{\circ} \mathrm{C}$ in $1999,1973^{\circ} \mathrm{C}$ in 2000 , and $1853^{\circ} \mathrm{C}$ in 2001 compared to a 20 -yr average of $1730^{\circ} \mathrm{C}$.

At physiological maturity, all plants in $1.5 \mathrm{~m}$ of two rows were harvested from each plot. Plants were separated into grain and stover, dried at $60^{\circ} \mathrm{C}$, and weighed. Subsamples of grain and stover were ground and analyzed for total C and $\mathrm{N}$ by dry combustion (Schepers et al., 1989) and total P colorimetrically following acid digestion (Bowman, 1989). Sorghum grain yield is reported at a moisture content of $140 \mathrm{~g} \mathrm{~kg}^{-1}$ while air-dry mass for grain and stover was used for nutrient content calculations.

\section{Clay Center}

Soil at the Clay Center site was a well drained Hastings silt loam (fine smectitic, mesic Udic Argiustoll) with a field average total $\mathrm{N}$ concentration of $0.8 \mathrm{~g} \mathrm{~kg}^{-1}$, an organic $\mathrm{C}$ concentration of $17 \mathrm{~g}$ $\mathrm{kg}^{-1}$, a Bray P concentration of $7.7 \mathrm{mg} \mathrm{kg}^{-1}$, a bulk density of 1.41 $\mathrm{g} \mathrm{cm}^{-3}$, and a $\mathrm{pH}$ of 6.7 in the 0 - to $15-\mathrm{cm}$ depth. The field had been in a conventionally tilled (fall disk tillage to incorporate crop residue, spring tillage with a field cultivator, and in-row cultivation to control weeds following crop germination) irrigated soybeancorn rotation. The field was planted to corn the year before this study. Treatments were applied at Site 1 in 1999 to 5 by 7 m plots arranged in a randomized complete block design with five replications. Nutrient treatments were surface applied (Table 1), incorporated with a field cultivator, and corn was planted. In 2000, plots at Site 1 were tilled and corn was planted with no additional nutrient application. In 2000, treatments were applied to an adjacent set of 5 by $7 \mathrm{~m}$ plots (Site 2) arranged in a randomize block design with five replications, incorporated, and corn was planted. In 2001, plots at Site 2 were tilled with a field cultivator and corn was planted with no additional nutrient application. Corn (Pioneer $33 \mathrm{~A} 14$ in 1999, 33G26 in 2000, and 33P67 in 2001) was planted in $76-\mathrm{cm}$ rows at a seeding rate to achieve a field population of 71,600 plants ha ${ }^{-1}$.

Precipitation from 1 May through 31 October totaled 42.2 $\mathrm{cm}$ in $1999,36.8 \mathrm{~cm}$ in 2000 , and $43.6 \mathrm{~cm}$ in 2001 . Irrigation provided an additional $20.1 \mathrm{~cm}$ of water in $1999,35.5 \mathrm{~cm}$ in 2000 , and $41.5 \mathrm{~cm}$ in 2001. Accumulated growing degree days (base $10^{\circ} \mathrm{C}$ ) from 1 May to 31 October were $1706^{\circ} \mathrm{C}$ in $1999,1849^{\circ} \mathrm{C}$ in 2000 , and $1769^{\circ} \mathrm{C}$ in 2001 compared to a 20 -yr average of $1730^{\circ} \mathrm{C}$. 
At physiological maturity all plants in $3 \mathrm{~m}$ of row were harvested from each plot. Plants were separated into grain and stover, dried at $60^{\circ} \mathrm{C}$, and weighed. Subsamples of grain and stover were ground and analyzed for total C, N, and P as described above. Corn grain yield is reported at a moisture content of $155 \mathrm{~g} \mathrm{~kg}^{-1}$ while air-dry mass for grain and stover was used for nutrient content calculations.

\section{Crop Nutrient Utilization}

Crop nutrient content was calculated by multiplying the $\mathrm{N}$ and $\mathrm{P}$ concentration $\left(\mathrm{kg} \mathrm{Mg}^{-1}\right)$ by grain and total (grain plus stover) dry matter produced $\left(\mathrm{Mg} \mathrm{ha}^{-1}\right)$. Results are reported as grain $\mathrm{N}$ and $\mathrm{P}$ content and total dry matter $\mathrm{N}$ and $\mathrm{P}$ content $\left(\mathrm{kg} \mathrm{ha}^{-1}\right)$. Crop utilization of applied nutrients was compared using the apparent recovery method (Motavalli et al., 1989). Crop nutrient utilization was calculated as grain or total dry matter nutrient content within a nutrient treatment minus grain or total dry matter nutrient content within the control divided by the amount of total $\mathrm{N}$ or $\mathrm{P}$ applied in that nutrient treatment. For the Rogers Farm study, where nutrients were applied each year, no attempt was made to account for nutrients remaining from the previous year's nutrient application. For the Clay Center study where nutrients were applied once at each site, crop nutrient utilization was calculated as described above in Year 1. For Year 2, the 2-yr combined nutrient content of the control was subtracted from the 2-yr combined crop nutrient content of the treatment and divided by nutrients applied during Year 1. The Year 2 nutrient utilization represents cumulative nutrient utilization for that treatment. Crop nutrient utilization is reported as a percentage of total $\mathrm{N}$ or $\mathrm{P}$ applied.

Analysis of variance was used to determine differences in grain and dry matter production, grain and dry matter $\mathrm{N}$ and $\mathrm{P}$ content, and crop nutrient utilization (SAS Institute, 1985). At the Rogers Farm the experimental design was completely random with repeated measures across years. At Clay Center, the experimental design was randomized blocks with two sites (the first site consisting of treatments applied in 1999 and the adjacent second site consisting of treatments applied in 2000) with repeated measures across years at each site. Differences were declared significant at the 0.05 probability level. Differences among means were determined by pair-wise comparisons made with the DIFF option of the LSMEANS statement. The Tukey adjustment option of the LSMEANS statement was used to protect the experiment-wise error rate.

\section{RESULTS AND DISCUSSION Rogers Farm}

Sorghum grain yield exhibited a treatment by year interaction $(P=0.008)$. Yields in the control treatment were lower than those in all nutrient treatments in all years and decreased over the course of the study (Fig. 1A). Grain yields in the inorganic fertilizer treatment were similar across years and were similar to yields in the two slurry treatments in 2000 but lower than yields in the two slurry treatments in 1999 and 2001. Grain yields in the TC slurry treatment were similar in 2000 and 2001. Grain yields for the LPC slurry treatment were similar in 1999 and 2000 and in 2000 and 2001. Grain yields in the TC slurry treatment were greater than yields in the LPC slurry treatment in 1999 and were similar in 2000 and 2001.

Total dry matter exhibited a treatment by year interaction $(P=$ 0.001). Dry matter production in the control treatment was lower than those in all the nutrient treatments and was greater in 1999 than in 2000 and 2001 (Fig. 1B). Dry matter production within a treatment in all three nutrient treatments was greater in 1999 and 2001 than in 2000. Dry matter production in the inorganic fertilizer treatment was lower than in the two slurry treatments in 1999 and 2000 and was similar to the LPC slurry treatment but lower than the TC slurry treatment in 2001. Dry matter production was similar in the two slurry treatments in each of the $3 \mathrm{yr}$.

Declining grain and dry matter production in the control reflects nutrient stress resulting from continuous cropping with no nutrient additions as reported by others (Evans et al., 1977; Ma et al., 1999a). Nutrient additions were most consistent in the inorganic fertilizer treatment and are reflected in similar grain production across years in that treatment. There was no evidence of reduced emergence or damaged seedlings resulting from the multiple years of slurry addition which is similar to what Evans et al. (1977) reported.

A treatment by year interaction $(P=0.02)$ was observed for sorghum grain $\mathrm{N}$ content. Grain $\mathrm{N}$ content in the control treatment was lower than in the nutrient treatments in all years and was lower in 2001 than in 1999 or 2000 (Fig. 2A). Grain N content in the inorganic fertilizer treatment was similar across years, was lower than the two slurry treatments in 1999 , and was similar to the LPC slurry treatment but less than the TC slurry treatment in 2000 and 2001. Grain N content was similar between the two slurry treatments in 2001 but greater in the TC slurry treatment than in the LPC slurry treatment in 1999 and 2000 and was greater in both

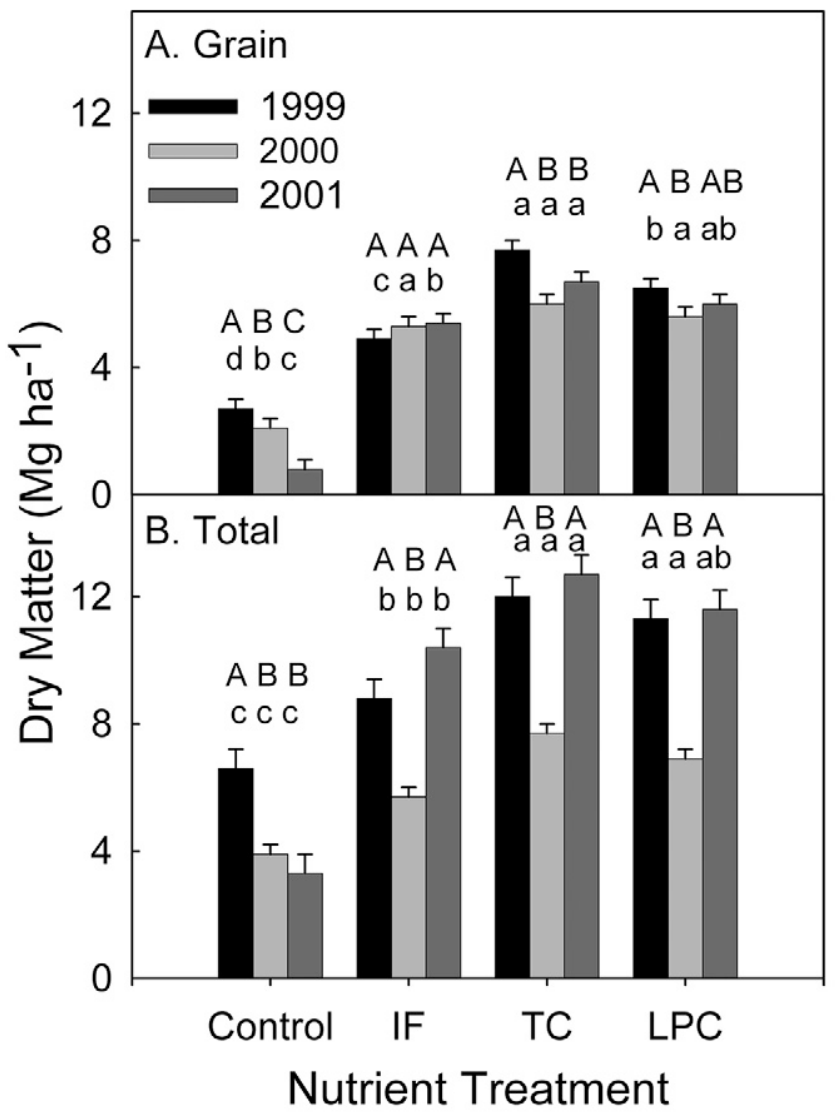

Fig. I. Sorghum (A) grain and (B) total dry matter production as a function of nutrient treatment and year at the Rogers Memorial Research Farm near Lincoln, NE. Error bars represent one standard error of the mean. Bars within a group having different uppercase letters or same shade bar among groups having a different lowercase letter above are different at $P<0.05$. 


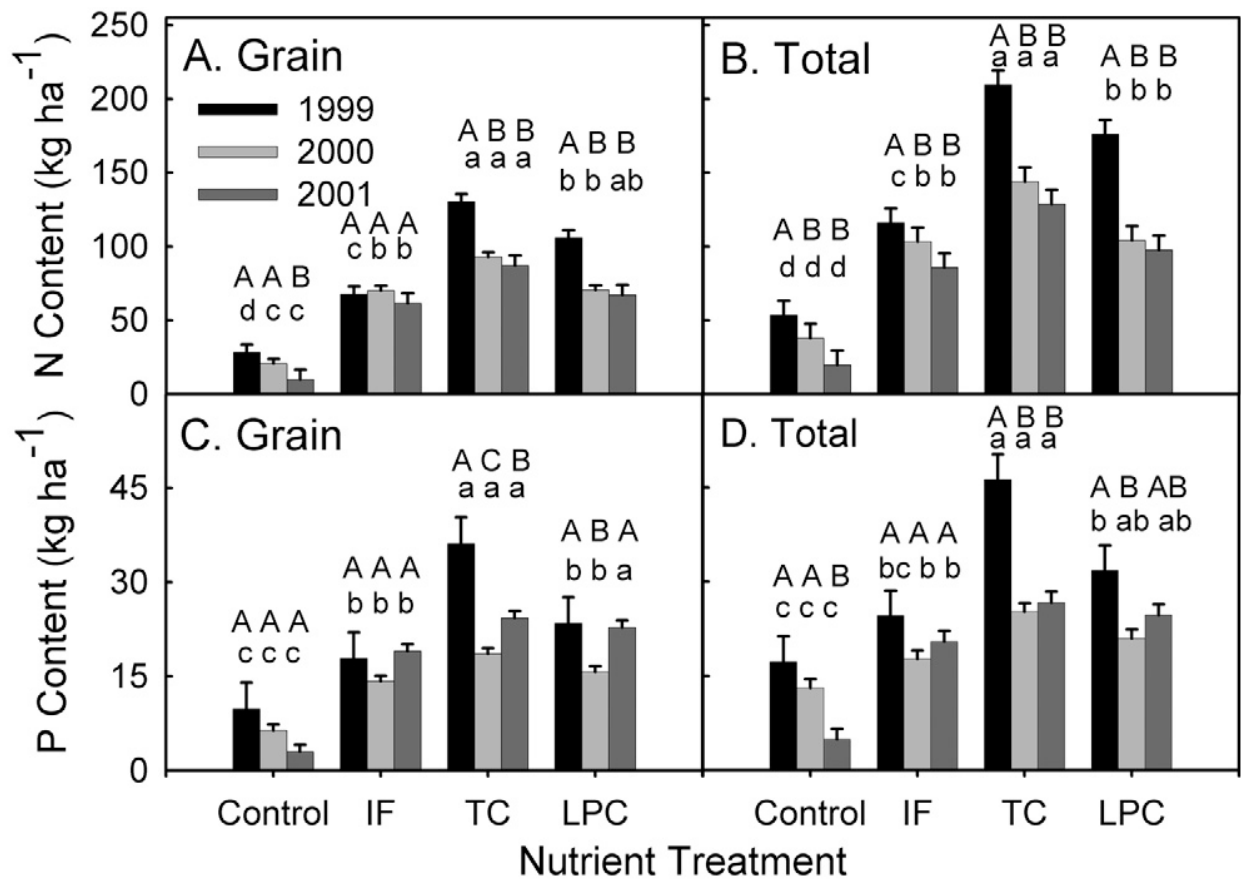

Fig. 2. Sorghum (A) grain and (B) total $N$ content and (C) grain and (D) total $P$ content as a function of treatment and year at the Rogers Memorial Research Farm near Lincoln, NE. Error bars represent one standard error of the mean. Bars within a group having different uppercase letters or same shade bar among groups having a different lowercase letter above are different at $P<0.05$.

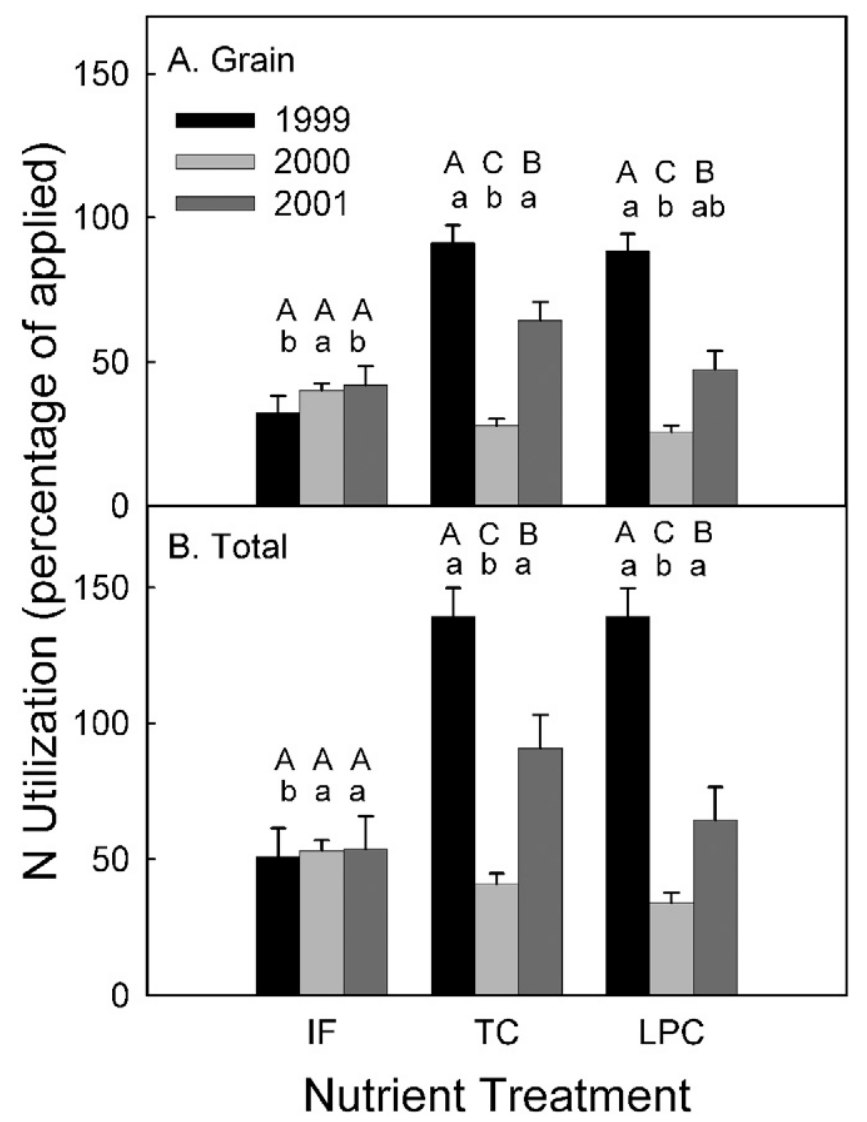

Fig. 3. Sorghum (A) grain and (B) total dry matter $\mathbf{N}$ utilization expressed as a percentage of $\mathbf{N}$ applied as a function of nutrient treatment and year at the Rogers Memorial Research Farm near Lincoln, NE. Error bars represent one standard error of the mean. Bars within a group having different uppercase letters or same shade bar among groups having a different lowercase letter above are different at $P<0.05$. slurry treatments in 1999 than in 2000 and 2001. Sorghum total dry matter $\mathrm{N}$ content exhibited a year effect $(P<0.001)$ being greater in 1999 than in 2000 and 2001 in all nutrient treatments (Fig. 2B). Dry matter $\mathrm{N}$ content also exhibited a treatment effect $(P<0.001)$, declining in the order TC slurry treatment $>$ LPC slurry treatment $=$ inorganic fertilizer $>$ control.

A treatment by year interaction $(P<0.001)$ was observed for sorghum grain P content. Within the control and inorganic fertilizer treatments, grain $P$ content was similar across years (Fig. 2C). Grain P content was lower in the control than in all of the nutrient treatments in all years. Grain $\mathrm{P}$ content in the inorganic fertilizer treatment was similar to that in the LPC slurry treatment in 1999 and 2000 and was less than that in the LPC slurry treatment in 2001. Grain $\mathrm{P}$ content in the inorganic fertilizer treatment was less than in the TC slurry treatment in all 3 yr. Grain P content was lower in the LPC slurry treatment than in the TC slurry treatment in 1999 and 2000 but the two slurry treatments were similar in 2001. In the TC slurry treatment, grain P content decreased in the order $1999>2001>$ 2000 while in the LPC slurry treatment grain P content was similar in 1999 and 2001 and was greater in these $2 \mathrm{yr}$ than in 2000. Sorghum dry matter $P$ content exhibited a treatment by year interaction $(P<0.004)$. Dry matter $P$ content in the control was greater in 1999 and 2000 than in 2001 and was less than that in the nutrient treatments in all years (Fig. 2D). Dry matter P content in the inorganic fertilizer treatment was similar across years, was similar to dry matter P content in the LPC slurry treatment in all years, and was less than dry matter P content in the TC slurry treatment in all years. Dry matter $\mathrm{P}$ content in the TC slurry treatment was greater in 1999 than in 2000 and 2001 and was greater than in the LPC slurry treatment in 1999. Dry matter P content in the LPC slurry treatment was greater in 1999 and 2001 than in 2000.

Declining grain and dry matter nutrient content in the control treatment with time reflects decreasing nutrient availability with continuous cropping and no nutrient additions as mentioned above. Higher grain and dry matter nutrient contents in 1999 than in 2000 or 2001 in the nutrient treatments is the result of favorable growing conditions in 1999 compared to the hot and dry growing conditions in 2000 and 2001. Differences in grain and dry matter $\mathrm{N}$ and P content between the two slurry types is likely due to the higher application rates in the TC slurry treatment than in the LPC slurry treatment in 1999 and 2000 (Table 1).

A treatment by year interaction was observed for sorghum grain $(P<0.0001)$ and dry matter $(P<0.001) \mathrm{N}$ utilization. Grain (Fig. 3A) and dry matter (Fig. 3B) N utilization in the inorganic fertilizer treatment was similar across years. Grain and dry matter $\mathrm{N}$ utilization in the inorganic fertilizer treatment was lower than in the TC and LPC slurry treatments in 1999 and was greater 
than in the TC and LPC slurry treatments in 2000. Grain N utilization was similar to the LPC slurry treatment but less than the TC slurry treatment in 2001. Total dry matter $\mathrm{N}$ utilization in the inorganic fertilizer treatment was similar to that in the LPC and TC slurry treatments in 2001. Grain and dry matter $\mathrm{N}$ utilization in each year was similar between the two slurry treatments and in both slurry treatments was greatest in 1999 and decreased in the order $1999>2001>2000$. Sorghum grain P utilization exhibited a year effect $(P<0.0001)$. Grain $P$ utilization was lower in 2000 $(25.1 \pm 1.4 \%)$ than in $1999(44.4 \pm 7.0 \%)$ and $2001(57.0 \pm 2.2 \%)$. Sorghum dry matter $P$ utilization also exhibited a year effect $(P<$ 0.0001). Dry matter P utilization was lower in 2000 (20.0 $\pm 2.3 \%)$ than in 1999 (46.7 $\pm 6.9 \%)$ and $2001(56.7 \pm 3.6 \%)$.

Grain and dry matter nutrient utilization exhibited more yearto-year variation in the two slurry treatments than in the inorganic fertilizer treatment due to the effect of growing season weather on nutrient release from the manure and nutrient uptake by the plant and more variable application rates in the slurry treatments than in the IF treatment (Table 1). As $\mathrm{N}$ application rates increase, crop utilization of applied N decreases (Sims, 1987). High yearto-year variation in nutrient availability in manured soils has been reported by others and factors responsible for this variation have been elusive (Motavalli et al., 1989). Soils at our study site did not have a history of manure application and surface application of slurry may have stimulated decomposition and mineralization in these no-tillage soils in 1999 (Ma et al., 1999b). Coelho et al. (2006) reported $20 \% \mathrm{~N}$ utilization by corn following surface application of slurry 2 mo after planting. Our treatments were applied much earlier at crop emergence which may explain the higher crop $\mathrm{N}$ utilization in this study. Nutrient utilization in 2000 and 2001 was lower than in 1999 and may reflect the hot and dry growing conditions that occurred during those $2 \mathrm{yr}$.

\section{Clay Center}

Corn grain yield exhibited a site by treatment by year interaction (p 0.0002) and a treatment by year interaction $(P<0.0001)$. The three-way interaction resulted from lower grain yields in the control treatment at Site 2 than at Site 1 but similar grain yields within a nutrient treatment at both sites. Lower control yields at Site 2 than at Site 1 resulted from fertilizer application at Site 1 but not at Site 2 the year before our nutrient application. Since it was only the magnitude of the difference between yields in the control treatment and that in the nutrient treatments that differed between sites, grain yield was averaged across sites to simplify presentation of nutrient treatment effects. Corn grain yield was similar between years for the control but greater in Year 1 than Year 2 for the inorganic fertilizer, TC slurry, and LPC slurry treatments (Fig. 4A). In Year 1, corn grain yield was lower in the control treatment than in the nutrient treatments and yield was similar among the three nutrient treatments. In Year 2, grain yield in the control was similar to that in the TC slurry treatment and less than that in the inorganic fertilizer and LPC slurry treatments while grain yield among the three nutrient treatments was similar. Total dry matter also exhibited a treatment by year interaction $(P=0.027)$. Total dry matter was greater in Year 1 than in Year 2 for all treatments (Fig. 4B). In Year 1, total dry matter was lower in the control than in all nutrient treatments and was similar among the three nutrient treatments. In Year 2, total dry matter in the control and

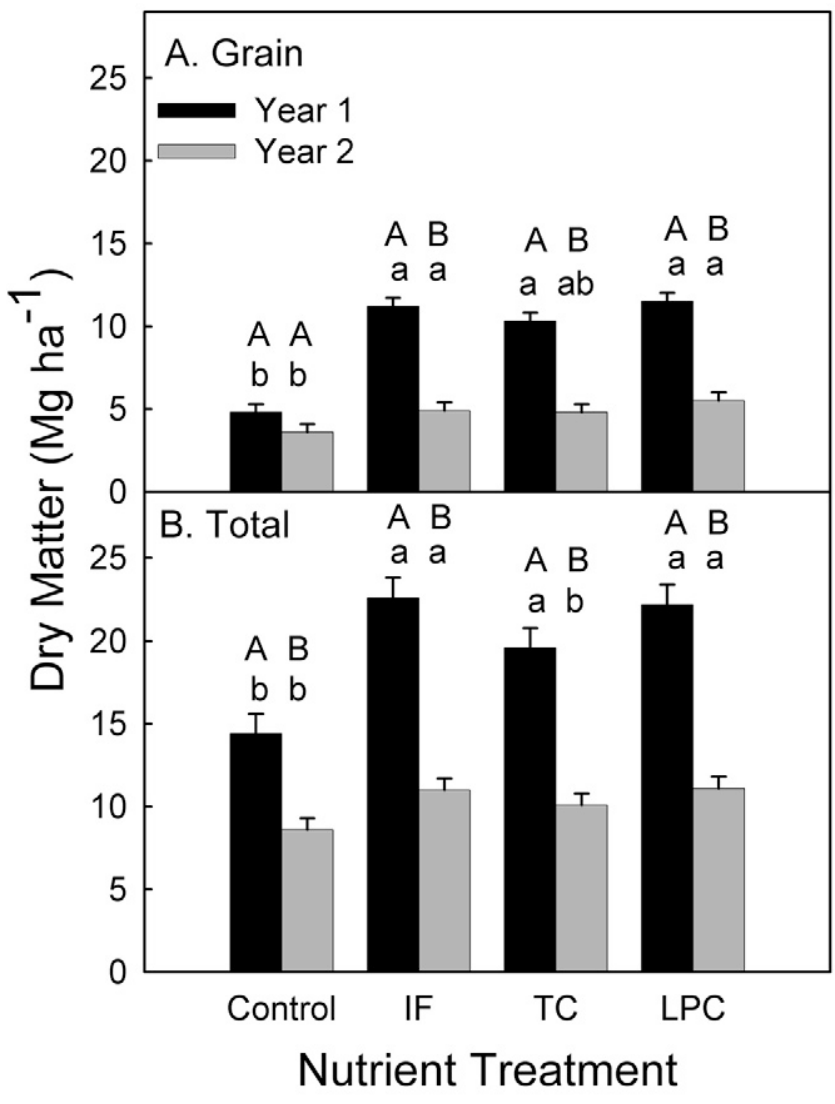

Fig. 4. Corn (A) grain and (B) total dry matter production during year of application and year following application as a function of nutrient treatment at Clay Center, NE. Error bars represent one standard error of the mean. Bars within a group having different uppercase letters or same shade bar among groups having a different lowercase letter above are different at $P<0.05$.

Table I. Swine slurry, total $\mathbf{N}$ and total $\mathrm{P}$ application rates for the Rogers Memorial Farm and Clay Center study sites.

\begin{tabular}{|c|c|c|c|c|}
\hline & \multicolumn{4}{|c|}{ Nutrient source $\dagger$} \\
\hline & TC & LPC & IF & Control \\
\hline \multicolumn{5}{|l|}{ Rogers Farm } \\
\hline \multicolumn{5}{|l|}{1999} \\
\hline Slurry, Mg ha- ${ }^{-1}$ & 25.5 & 25.5 & - & - \\
\hline $\mathrm{N}, \mathrm{kg} \mathrm{ha}^{-\mathrm{l}}$ & 112 & 88 & 123 & 0 \\
\hline $\mathrm{P}, \mathrm{kg} \mathrm{ha}^{-1}$ & 43 & 30 & 30 & 0 \\
\hline \multicolumn{5}{|l|}{2000} \\
\hline Slurry, Mg ha-1 & 35.1 & 20.7 & - & - \\
\hline $\mathrm{N}, \mathrm{kg} \mathrm{ha}^{-1}$ & 258 & 194 & 123 & 0 \\
\hline $\mathrm{P}, \mathrm{kg} \mathrm{ha}^{-1}$ & 57 & 34 & 30 & 0 \\
\hline \multicolumn{5}{|l|}{2001} \\
\hline Slurry, Mg ha- ${ }^{-1}$ & 30.0 & 24.1 & & \\
\hline $\mathrm{N}, \mathrm{kg} \mathrm{ha}^{-1}$ & 120 & $12 \mid$ & 123 & 0 \\
\hline $\mathrm{P}, \mathrm{kg} \mathrm{ha}^{-1}$ & 40 & 31 & 30 & 0 \\
\hline \multicolumn{5}{|l|}{ Clay Center } \\
\hline \multicolumn{5}{|l|}{1999} \\
\hline Slurry, Mg ha ${ }^{-1}$ & 42.7 & 42.7 & - & - \\
\hline $\mathrm{N}, \mathrm{kg} \mathrm{ha}^{-1}$ & 178 & 123 & 179 & 0 \\
\hline $\mathrm{P}, \mathrm{kg} \mathrm{ha}^{-1}$ & 68 & 42 & 50 & 0 \\
\hline \multicolumn{5}{|l|}{2000} \\
\hline Slurry, $\mathrm{Mg} \mathrm{ha}^{-1}$ & 50.8 & 46.4 & - & - \\
\hline $\mathrm{N}, \mathrm{kg} \mathrm{ha}^{-1}$ & 175 & 271 & 179 & 0 \\
\hline $\mathrm{P}, \mathrm{kg} \mathrm{ha}^{-1}$ & 54 & 58 & 50 & 0 \\
\hline
\end{tabular}

$\dagger \mathrm{TC}=$ manure from swine fed a traditional corn diet, $\mathrm{LPC}=$ manure from swine fed a low phytate corn diet, IF = inorganic fertilizer. 


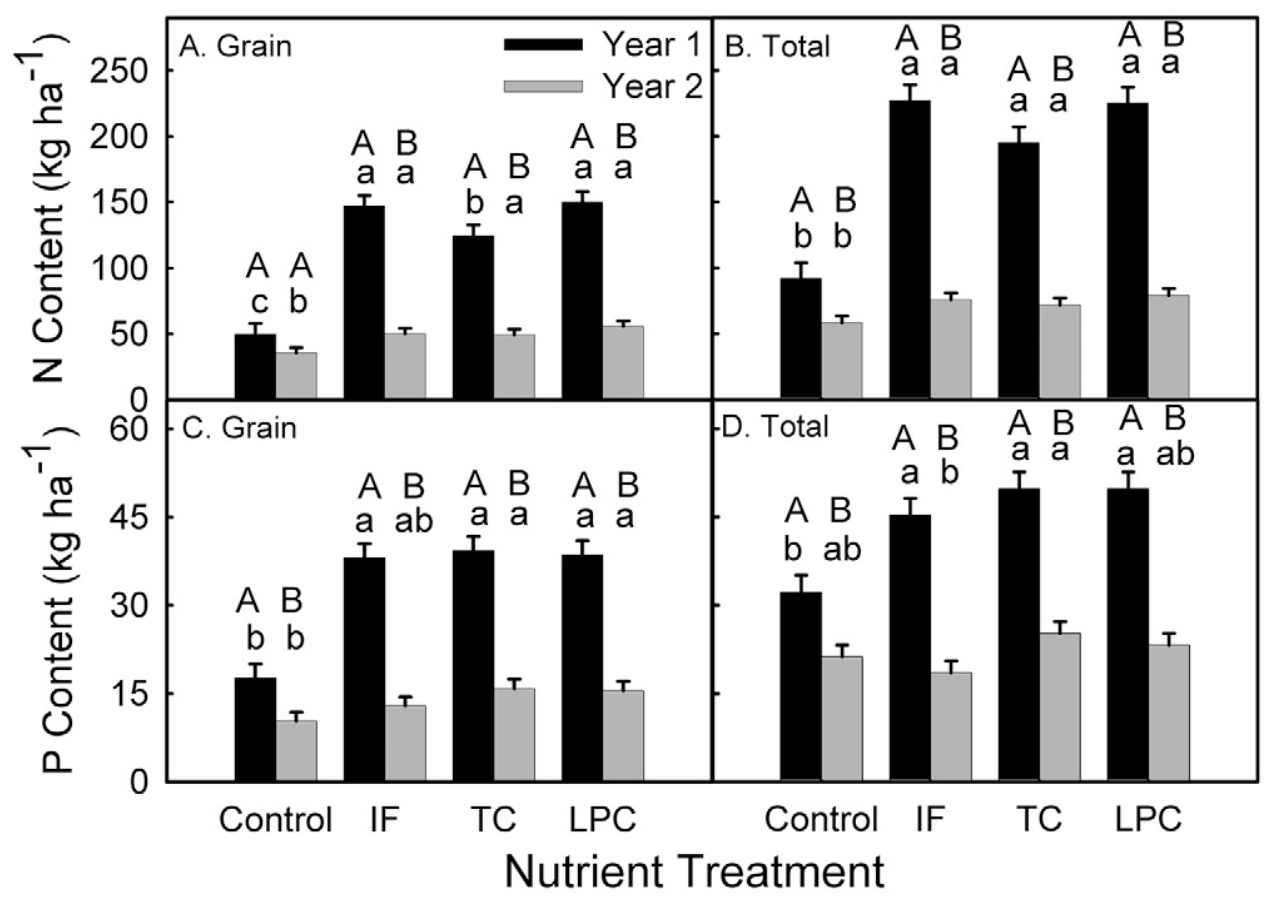

Fig. 5. Corn (A) grain and (B) total $N$ content and (C) grain and (D) total $P$ content during year of application and year following application as a function of nutrient treatment at $C$ lay Center, NE. Error bars represent one standard error of the mean. Bars within a group having different uppercase letters or same shade bar among groups having a different lowercase letter above are different at $P<0.05$.

TC slurry treatments were similar but less than total dry matter in the inorganic fertilizer and LPC slurry treatments.

Lower grain and dry matter production in the control than in the nutrient treatments in Year 1 reflects nutrient stress that occurs when no nutrients are added to these continuously cropped soils. Similar grain and dry matter production among the nutrient treatments in Year 1 demonstrates that crop response to these three nutrient sources was similar. In contrast, Kwaw-Mensah and Al-Kaisi (2006) reported higher relative corn grain yields with swine slurry addition than with inorganic fertilizer. Higher yields with swine slurry would result if soils at their site were deficient in a nutrient that was present in the slurry but not in inorganic fertilizer. Lower grain and dry matter production in Year 2 than Year 1 implies that residual nutrient availability from the previous year's nutrient application were not sufficient to support high levels of production in these soils (Cusick et al., 2006).

A site by treatment by year interaction $(\mathrm{p} 0.02)$ and a treatment by year interaction $(P<0.0001)$ was observed for corn grain $\mathrm{N}$ content. The three-way interaction resulted from lower grain $\mathrm{N}$ content in the control treatment at Site 2 than at Site 1 but similar grain $N$ content within a nutrient treatment at both sites. Since it was only the magnitude of the difference between grain $\mathrm{N}$ content in the control treatment and that in the nutrient treatments that differed between sites, grain $\mathrm{N}$ content was averaged across sites to simplify presentation of nutrient treatment effects. Grain N content was similar for both years in the control treatment but was greater in Year 1 than in Year 2 for the three nutrient treatments

(Fig. 5A). In Year 1, grain N content was lower in the control than in the three nutrient treatments and was lower in the TC slurry treatment than in the inorganic fertilizer and LPC slurry treatments. Total dry matter $\mathrm{N}$ content exhibited a treatment by year interaction $(P<0.0001)$. Corn total dry matter $\mathrm{N}$ content was greater in Year 1 than in Year 2 for all treatments (Fig. 5B). Dry matter $\mathrm{N}$ content was lower in the control than in the three nutrient treatments for both years and was similar among the three nutrient treatments in each of the 2 yr.

Corn grain $\mathrm{P}$ content exhibited a treatment by year interaction $(P<0.0001)$. In Year 1 , grain $P$ content was lower in the control than in the three nutrient treatments while in Year 2 grain $\mathrm{P}$ content was similar in the control and inorganic fertilizer treatments, lower in the control than in the two slurry treatments, and similar among the three nutrient treatments (Fig. 5C). Corn total dry matter $P$ content also exhibited a treatment by year interaction $(P<0.0001)$. In Year 1 , dry matter $P$ content was lower in the control than in the three nutrient treatments while in Year 2 dry matter $P$ content was lower in the inorganic fertilizer treatment than in the TC slurry treatment, was similar among the control, inorganic fertilizer, and LPC slurry treatments, and was similar among the control and both slurry treatments (Fig. 5D).

Lower grain and dry matter nutrient content in the control during Year 1 reflects the limited nutrient supplying availability of these annually cropped soils. Lack of site differences in yield and nutrient content for the nutrient addition treatments are due to similar input of nutrients, irrigation reducing moisture stress, and weather conditions that were favorable for corn growth during the $3 \mathrm{yr}$ of this study $(P>$ $0.14)$. Similar nutrient content among the nutrient treatments demonstrates that all three nutrient sources provided sufficient $\mathrm{N}$ and $\mathrm{P}$ for corn production in the year of application while the reduced nutrient content in Year 2 demonstrates that immobilization in soil microbial biomass and decompos- 


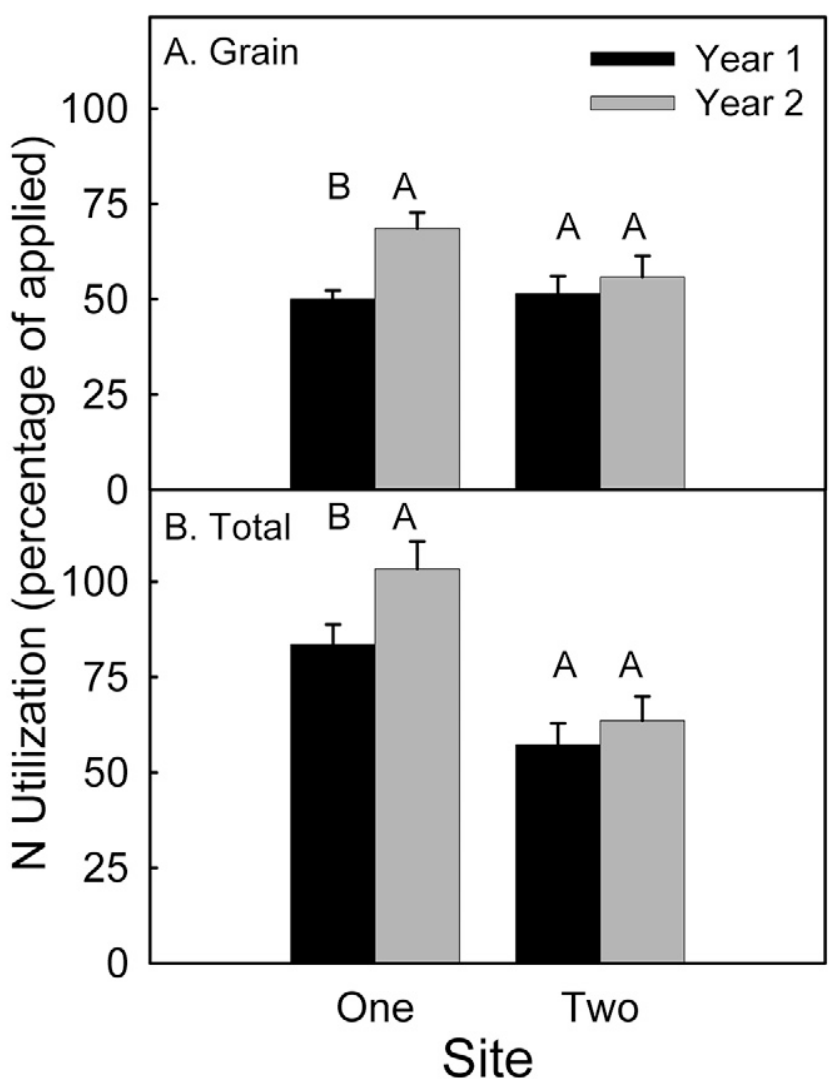

Fig. 6. Corn (A) grain and (B) total dry matter $\mathbf{N}$ utilization expressed as a percentage of $\mathbf{N}$ applied during year of application and year following application as a function of site at Clay Center, NE. Error bars represent one standard error of the mean. Bars having different uppercase letters above are different at $P<0.05$.

ing crop residue limits residual $\mathrm{N}$ and $\mathrm{P}$ availability to subsequent crops (Cusick et al., 2006).

A site by year interaction $(P=0.0007)$ was observed for corn grain $\mathrm{N}$ utilization. At Site 1, grain $\mathrm{N}$ utilization increased from Year 1 to Year 2 while at Site 2 it was similar for both years (Fig. 6A). Similarly, corn total dry matter $\mathrm{N}$ utilization exhibited a site by year interaction $(P=0.016)$. At Site 1 , total dry matter $\mathrm{N}$ utilization increased from Year 1 to Year 2 while at Site 2 it was similar for both years (Fig. 6B). Site 1 received fertilizer the year before application of our nutrient treatments while Site 2 did not. Site 2 was likely more nutrient depleted than Site 1 after growing an unfertilized corn crop. Lack of an increase in $\mathrm{N}$ utilization for Year 2 at Site 2 is likely due to this lower soil nutrient status. Our nutrient applications provided $\mathrm{N}$ for crop uptake, soil microorganism activity, and for crop uptake in Year 2. Growing the unfertilized corn crop before our nutrient application resulted in less $\mathrm{N}$ for crop uptake in Year 2 at Site 2.

Corn grain $\mathrm{P}$ utilization differed between years $(P=0.0004)$ and increased from Year $1(40.4 \pm 3.0 \%)$ to Year $2(50.2 \pm$ 4.5\%). Corn total dry matter P utilization exhibited a site by year interaction $(P=0.046)$. During Year 1 , dry matter $P$ utilization was greater at Site 2 than at Site 1 while in Year 2 dry matter P utilization was similar between sites (Table 2). There was no difference in dry matter P utilization between years at either site.

Lack of differences in $\mathrm{N}$ and $\mathrm{P}$ utilization among the nutrient sources demonstrates that nutrient availability to corn was similar between the two slurry types. Similarity in nutrient
Table 2. Apparent corn total dry matter $P$ use as a function of time since application and site for the Clay Center research site.

\begin{tabular}{lll}
\hline & \multicolumn{2}{c}{ Yeart } \\
\cline { 2 - 3 } Site & \multicolumn{1}{c}{ First } & Second \\
\cline { 2 - 3 } & & \\
\hline & $26.7 \pm 4.9$ a B $\neq$ & $36.6 \pm 7.0$ a A \\
Average & $34.4 \pm 5.2$ a A & $31.0 \pm 9.3$ a A \\
& $30.6 \pm 3.2$ a & $33.8 \pm 5.2$ a
\end{tabular}

$\dagger$ Year: first designates year of application, second designates year after application. $\ddagger$ Mean \pm SE, means within a row followed by different lowercase letters are different at $P<0.05$, means within a column followed by different uppercase letters are different at $P<0.05$.

utilization between inorganic fertilizer and slurry differs from other studies where higher nutrient utilization was observed for inorganic fertilizer than for slurry or manure (Bergström and Kirchmann, 2006). The small increase in grain $\mathrm{N}$ and $\mathrm{P}$ utilization during Year 2 at Site 1 and similar utilization across years at Site 2 agrees with other studies that have reported little residual nutrient availability in years subsequent to the year of application (Klausner et al., 1994; Chantigny et al., 2004; Cusick et al., 2006).

\section{Management Implications}

Slurry from swine fed a TC diet has a lower $\mathrm{N}$ to $\mathrm{P}$ ratio (3.3 vs. 4.5) than did slurry from swine fed a LPC diet (Wienhold and Miller, 2004). The $\mathrm{N}$ to P ratio for both slurry types are lower than what is required by a corn crop so that application of swine slurry at rates to meet the $\mathrm{N}$ needs of the crop should provide sufficient $\mathrm{N}$ and excess $\mathrm{P}$ to meet crop needs. Based on corn and sorghum yields, $\mathrm{N}$ and $\mathrm{P}$ content, and $\mathrm{N}$ and $\mathrm{P}$ utilization during the year of application there was no evidence of reduced nutrient availability in the LPC slurry compared to the TC slurry in the present study. High crop available P from LPC slurry supports conclusions from manure $P$ fractionation and soil incubation studies that while the amount of $\mathrm{P}$ relative to $\mathrm{N}$ is lower in LPC slurry than in TC slurry the availability of that $\mathrm{P}$ is similar (Gollany et al., 2003; Leytem et al., 2004; Wienhold and Miller, 2004). While available P in manured soils remains elevated in subsequent years the availability of manure $\mathrm{N}$ in subsequent years is low. Chantigny et al. (2004) applied ${ }^{15} \mathrm{~N}$ labeled swine slurry to a clay soil and found $29 \%$ in a corn crop grown the year of application and only $3 \%$ in a subsequent barley crop.

Annual applications of swine slurry at $\mathrm{N}$ rates to satisfy crop demands have been shown to result in accumulation of soil $\mathrm{P}$ with greater accumulation using TC slurry than with LPC slurry (Wienhold, 2005). Two approaches for reducing the rate of $\mathrm{P}$ accumulation are to either apply slurry at a rate to meet crop $\mathrm{P}$ needs and satisfy crop $\mathrm{N}$ needs with additional inorganic fertilizer $\mathrm{N}$ or apply swine slurry at a rate to meet crop $\mathrm{N}$ needs and apply only inorganic fertilizer $\mathrm{N}$ in subsequent years until soil $\mathrm{P}$ is reduced. Both approaches would require more land than annual slurry additions at crop $\mathrm{N}$ rates (Lory et al., 2004b) but the area would be less with LPC slurry than with TC slurry. The lower $\mathrm{N}$ to $\mathrm{P}$ ratio of LPC slurry will require less supplemental fertilizer $\mathrm{N}$ when slurry is applied at crop $\mathrm{P}$ rates and will result in slower accumulation of soil P than use of TC slurry when applied at crop $\mathrm{N}$ rates. Conservation of $\mathrm{N}$ during slurry 
storage would enhance the advantage of LPC for providing N and $\mathrm{P}$ in amounts required by a crop.

We know of no previous field research comparing crop utilization of nutrients provided by manure from animals fed LPC to that of animals fed TC. Our field results demonstrate that grain and dry matter $\mathrm{N}$ and $\mathrm{P}$ utilization when nutrients were provided as LPC slurry were similar to that when nutrients were provided as inorganic fertilizer. Based on results from this initial study we conclude that current recommendations for land application of swine slurry should pertain to LPC slurry.

\section{ACKNOWLEDGMENTS}

Authors thank Cliff Hunter (deceased) and Dave Althouse for maintenance of the field sites, Andrew Pond for assistance in the field, Pioneer Hi-Bred for providing seed, and Susan SiragusaOrtman and Susan Wagner for laboratory analyses.

\section{REFERENCES}

Bergström, L., and H. Kirchmann. 2006. Leaching and crop uptake of nitrogen and phosphorus from pig slurry as affected by different application rates. J. Environ. Qual. 35:1803-1811.

Bowman, R.A. 1989. A rapid plant digest method for analysis of $\mathrm{P}$ and certain cations by inductive coupled plasma emission spectrometry. Commun. Soil Sci. Plant Anal. 20:539-553.

Chantigny, M.H., D.A. Angers, T. Morvan, and C. Pomar. 2004. Dynamics of pig slurry nitrogen in soil and plant as determined with ${ }^{15} \mathrm{~N}$. Soil Sci. Soc. Am. J. 68:637-643.

Coelho, B.R., R.C. Roy, and A.J. Bruin. 2006. Nitrogen recovery and partitioning with different rates and methods of sidedressed manure. Soil Sci. Soc. Am. J. 70:464-473.

Cusick, P.R., K.A. Kelling, J.M. Powell, and G.R. Muñoz. 2006. Estimates of residual dairy manure nitrogen availability using various techniques. J. Environ. Qual. 35:2170-2177.

Ertl, D.S., K.A. Young, and V. Raboy. 1998. Plant genetic approaches to phosphorus management in agricultural production. J. Environ. Qual. 27:299-304

Evans, S.D., P.R. Goodrich, R.C. Munter, and R.E. Smith. 1977. Effects of solid and liquid beef manure and liquid hog manure on soil characteristics and on growth, yield, and composition of corn. J. Environ. Qual. 6:361-368.

Gollany, H.T., M.A. Schmitt, P.R. Bloom, G.W. Randall, and P.R. Carter. 2003. Extractable phosphorus following soil amendment with manure from swine fed low-phytate corn. Soil Sci. 168:606-616.
Kwaw-Mensah, D., and M. Al-Kaisi. 2006. Tillage and nitrogen source and rate effects on corn response in corn-soybean rotation. Agron. J. 98:507-513.

Klausner, S.D., V.R. Kanneganti, and D.R. Bouldin. 1994. An approach for estimating a decay series for organic nitrogen in animal manure. Agron. J. 86:897-903.

Koelsch, R., and C. Shapiro. 1997. Determining crop available nutrients from manure. NebGuide G97-1335-A. Univ. of Nebraska, Lincoln.

Leytem, A.B., B.L. Turner, and P.A. Thacker. 2004. Phosphorus composition of manure from swine fed low-phytate grains: Evidence for hydrolysis in the animal. J. Environ. Qual. 33:2380-2383.

Lory, J.A., R.E. Massey, J.M. Zulovich, J.A. Hoehne, A.M. Schmidt, M.S. Carlson, and C.D. Fulhage. 2004a. An assessment of nitrogen-based manure application rates on 39 U.S. swine operations. J. Environ. Qual. 33:1106-1113.

Lory, J.A., R.E. Massey, J.M. Zulovich, J.A. Hoehne, A.M. Schmidt, M.S. Carlson, and C.D. Fulhage. 2004b. Feasibility and costs of phosphorus application limits on 39 U.S. swine operations. J. Environ. Qual. 33:1114-1123.

Ma, B.L., L.M. Dwyer, and E.G. Gregorich. 1999a. Soil nitrogen amendment effects on nitrogen uptake and grain yield of maize. Agron. J. 91:650-656.

Ma, B.L., L.M. Dwyer, and E.G. Gregorich. 1999b. Soil nitrogen amendment effects on seasonal nitrogen mineralization and nitrogen cycling in maize production. Agron. J. 91:1003-1009.

Motavalli, P.P., K.A. Kelling, and J.C. Converse. 1989. First-year nutrient availability from injected dairy manure. J. Environ. Qual. 18:180-185.

SAS Institute. 1985. SAS user's guide. SAS Inst., Cary, NC.

Schepers, J.S., D.D. Francis, and M.T. Thompson. 1989. Simultaneous determination of total $\mathrm{C}$, total $\mathrm{N}$, and ${ }^{15} \mathrm{~N}$ on soil and plant material. Commun. Soil Sci. Plant Anal. 20:949-959.

Sharpley, A.N., S.C. Chapta, R. Wedepohl, J.T. Sims, T.C. Daniel, and K.R. Reddy. 1994. Managing agricultural phosphorus for protection of surface waters: Issues and options. J. Environ. Qual. 23:437-451.

Sims, J.T. 1987. Agronomic evaluation of poultry manure as a nitrogen source for conventional and no-tillage corn. Agron. J. 79:563-570.

Spencer, J.D., G.L. Allee, and T.E. Sauber. 2000. Phosphorus bioavailability and digestibility of normal and genetically modified low-phytate corn for pigs. J. Anim. Sci. 78:675-681.

Wienhold, B.J. 2005. Changes in soil attributes following low phosphorus swine slurry application to no-tillage sorghum. Soil Sci. Soc. Am. J. 69:206-214.

Wienhold, B.J., and P.S. Miller. 2004. Phosphorus characterization in manure from swine fed traditional and low phytate corn diets. J. Environ. Qual. 33:389-393.

Wodzinski, R.J., and A.H. Ulla. 1996. Phytase. Adv. Appl. Microbiol. 42:263-302. 